\title{
De la novela al cine y el teatro: operatividad teórica de la autoficción*
}

\section{From the novel to the cinema and the theatre: autofiction's theoretical operativeness}

\author{
Ana Casas \\ Universidad de Alcalá \\ ana.casas@uah.es \\ ORCID iD: http://orcid.org/0000-0003-4792-246X
}

\section{RESUMEN}

El presente artículo tiene por objeto confirmar la operatividad de la noción de autoficción con respecto a otras manifestaciones artísticas distintas de la novela, en especial el cine y el teatro. Estas (con las particularidades que las caracterizan) plantean nuevos retos para el estudio de la representación ficcional del autor: la identificación problemática entre autor, director, actor y personaje (pues dicha identidad no es siempre total o exacta), así como los procedimientos retóricos específicamente espectaculares, que apelan a la imagen y no solo a la palabra, abren vías de reflexión inexploradas.

Palabras Clave: autoficción; teoría de los géneros; cine; teatro.

\begin{abstract}
The aim of the present article is to confirm the operativeness of the notion of autofiction with regard to artistic manifestations other than the novel, especially the cinema and the theatre. These productions (with their particularities) raise new challenges for the study of the author's fictional representation: the problematic identification between author, director, actor and character (since this identity is not always complete or exact), and also the rhetorical procedures particular to its spectacular dimension (which appeal not only to the image but also to the word) open unexplored paths for reflection.
\end{abstract}

Key words: Autofiction; Genre Theory; Cinema; Theatre.

* Este trabajo forma parte del proyecto «Figuraciones del yo y representación autoficcional en narrativa, cine, teatro y novela gráfica en el marco de la teoría de los géneros», financiado por el Subprograma Ramón y Cajal (MICINN-RYC) 2011. De igual modo se enmarca en el Proyecto del Plan Nacional «La autoficción hispánica. Perspectivas interdisciplinarias y transmediales. 1980-2013» (FFI2013-40918-P), financiado por el Ministerio de Economía y Competitividad. 


\section{INTRODUCCIÓN}

Desde el nacimiento del término y su desarrollo posterior como concepto, la autoficción ha sido objeto de dos clases de aproximaciones teóricas. Por un lado, Serge Doubrovsky, como artífice del neologismo, inauguró una línea de estudio que entendía la autoficción como una suerte de autobiografía experimental que se centraba, por lo tanto, en los aspectos referenciales: tomando como ejemplo su novela Fils (1977), los hechos narrados eran reales, pero la modulación discursiva y retórica de la obra la alejaba del grado cero de la escritura (habitualmente asociado a la versión clásica de la autobiografía) para adoptar, en cambio, los modos y formas de la novela. Desde esta perspectiva, podrían leerse algunas obras del mismo Doubrovsky, pero también de Philip Forest, Annie Ernaux o Jorge Semprún, por poner algunos ejemplos suficientemente dispares pero coincidentes en algunos de sus rasgos: se trata de relatos que narran acontecimientos reales de las vidas de sus autores, al tiempo que explicitan (y tematizan) las dificultades intrínsecas a toda escritura autobiográfica. Autorizados a «tomarse conscientemente (es decir, contractualmente con el lector) libertades con $s u$ verdad [...] romper la linealidad y la ilusoria objetividad de la reminiscencia, [...] autorizar digresiones, viajes imaginarios o, incluso, testimonios inconscientes» (Schmitt 2007: 24), estos autores pergeñarían narraciones dubitativas, en las que el recuerdo se reconstruye de manera fragmentaria como la expresión de un fracaso y, a menudo, del dolor causado por una herida afectiva o moral: el encierro en los campos de concentración (La escritura y la vida, 1994, de Jorge Semprún), la muerte de la hija (El niño eterno, 1997, de Philip Forest), el aborto clandestino (El acontecimiento, 2000, de Annie Ernaux) son los núcleos temáticos sobre los que, efectivamente, se construyen estas narraciones que emprenden, aunque por distintos caminos, la recomposición precaria de una identidad dañada. Por esa razón, no es extraño que muchos de estos textos toquen puntos sensibles de grupos sociales minoritarios o de escasa consideración (así, las cuestiones identitarias que conciernen a mujeres, judíos u homosexuales $)^{1}$. De hecho, la autoficción como idea (no como práctica, pues sería exagerado afirmar que esta modalidad narrativa nace de repente en 1977 con Doubrovsky) surge con la vocación de dar voz a los excluidos de los «grandes relatos»: «¿Autobiografía? - leemos en la contracubierta de Fils- No, ese es un privilegio reservado a los importantes de este mundo, en el otoño de su vida y en un estilo bello». La autoficción sería,

${ }^{1}$ En esta dirección resultan muy sugerentes los estudios de Régine Robin (1997), quien vincula la autoficción a la escritura judía y al Holocausto como respuesta a la experiencia traumática, y de Madeleine Ouellette-Michalska (2007) y Annie Richard (2013) en torno a la literatura de género. Puede consultarse también el trabajo de Souquet (2014) sobre autoficción e identidad sexual. 
pues, una especie de autobiografía bastarda en la que confluirían escrituras marginales y descentradas, desviadas del canon en más de un sentido.

Los trabajos de Vicent Colonna (1989 y 2004) constituyen una segunda línea de análisis con respecto a la autoficción, entendida ahora como la serie de procedimientos empleados en la ficcionalización del autor. Esta concepción mucho menos restrictiva que la de Doubrovsky solo tiene una condición: que no quepa la más mínima duda con respecto a la ficcionalidad de la obra. Operación Shylock (1998), de Philip Roth, Soldados de Salamina (2001), de Javier Cercas, o El mapa y el territorio (2010), de Michel Houellebecq, se las ingenian para deshacer la ambigüedad con respecto al estatuto genérico de la obra: son novelas y las consideramos autoficciones porque sus autores se proyectan ficcionalmente en la obra con la intención, entre otros propósitos, de problematizar, incluso de negar, la supuesta referencialidad del yo autorial. Las estrategias son variadas: en algunos casos se sustrae el protagonismo al autor, que, como en Soldados de Salamina o El mapa y el territorio, queda relegado a un segundo plano de la acción ${ }^{2}$. En la novela de Cercas, el personaje que lo encarna es un periodista que trata de reconstruir un episodio de la Guerra Civil en torno a dos personajes centrales: el escritor falangista Rafael Sánchez Mazas, que se salvó de milagro de un fusilamiento, y el republicano Miralles, que acaba erigiéndose en verdadero protagonista (y héroe anónimo) del relato; en El mapa y el territorio, Michel Houellebecq solo aparece ya avanzada la narración, cuando su protagonista, el artista plástico Jed Martin, le pide que redacte el catálogo de su próxima exposición. Que el personaje de Houellebecq muera al final (decapitación incluida) constituye un elemento de desreferencialización definitivo, en la medida en que, hasta donde sabemos, por esas fechas el Houellebecq real seguía vivo y coleando, inmerso en la promoción de su novela. La inclusión de inverosimilitudes como esta - o mejor sería decir desacuerdos flagrantes con la realidad empírica - es un recurso habitual en esta clase de obras: en Operación Shylock, por ejemplo, la referencialidad del relato se ve cuestionada casi desde el inicio gracias a la presencia de sucesos improbables, en especial el encuentro casi fantástico de Philip Roth con su doble en Israel.

Sin embargo, a lo largo de la historia de este concepto, las reflexiones sobre la autoficción se han interesado a menudo por los aspectos de índole pragmática que propician el llamado «pacto ambiguo» (Alberca 2007). Ello ha provocado que, desde determinadas perspectivas, la autoficción dependa en exceso del referente, cuando, de hecho, determinar hasta qué punto una obra es más o menos fiel con respecto a una vida, o hasta qué punto la proyección ficcional

${ }^{2}$ Esta posición «marginal» del autor se ve potenciada por el tipo de voz narradora: frente a la primera persona que facilita la identificación Autor $=$ Narrador $=$ Personaje, la novela de Houellebecq no solo escoge la tercera persona, sino que adopta mayoritariamente la perspectiva del protagonista, que es a todas luces un personaje de ficción. 
del autor hace justicia a la persona real, no aclara demasiado sobre el funcionamiento de un texto. Por este motivo, algunas voces recientes proponen trascender la dimensión referencial —incluso autobiográfica-de la autoficción, para concentrarse en los dispositivos irónicos que separan el yo figurado del yo real. Así lo entiende José María Pozuelo Yvancos (2010), cuando acuña precisamente la expresión «figuración del yo», como indicativo de la textualización de la voz autorial, evitando el escollo de la verificación. O Julio Premat (2009), en su caso en el contexto de la literatura argentina, al ocuparse de la vertiente «negativa» de la autoficción — «figura de autor» la denomina él一, en la que sitúa a escritores tan diversos como Macedonio Hernández, Jorge Luis Borges, Ricardo Piglia o César Aira, cuyas proyecciones autoriales resultan inexactas, fragmentadas, tramposas, parodiadas, como reflejos de una identidad en potencia que nunca llega a confirmarse.

De manera paralela, otros críticos han tratado de «devolver» a la autoficción sus orígenes referenciales, no ya desde presupuestos pragmáticos, sino desde la asunción de propuestas, conceptos e ideas que provienen de otros campos distintos de la crítica literaria, como la sociología, la poética cognitiva o la filosofía. En este sentido, resultan estimulantes las reflexiones de Jerôme Meizoz (2007), que retoman algunos estudiosos de la autoficción, como Pablo Decock (2014 y 2015) y Sonia Gómez (2015), sobre el lugar que ocupa el autor en el campo literario dentro del contexto de una sociedad - la nuestra-, organizada sobre los cánones del capitalismo y la mundialización: la identidad de los creadores se ve continuamente subrayada por los media que, de distintas formas, promocionan o visibilizan sus obras y, a veces incluso, sus personalidades, de manera que su papel público ejerce una importante influencia en la recepción que hacemos de los textos y en las correspondencias que somos capaces de establecer entre la persona y su proyección ficcional. En este sentido, la sociología literaria permite evaluar la interacción entre receptor y creador en un nivel que trasciende lo textual pero que, sin duda, se proyecta en lo textual.

Por su parte, Arnaud Schmitt (2007, 2010, 2011 y 2014) ha profundizado en las conexiones entre la autoficción y la poética cognitiva en varios trabajos en los que rebate la idea, hartamente repetida, según la cual la recontextualización de los elementos referenciales — sometidos a parodia y deconstruidos a la vez que exhibidos en el texto- genera en las obras autoficcionales una indeterminación en los pactos de lectura. De esta manera, pone en entredicho la posibilidad - que tradicionalmente han defendido los teóricos de la autoficción - de dos pactos simultáneos (autobiográfico y ficcional), para postular, al contrario, la existencia de pactos consecutivos gracias a tener lugar actos de lectura diversos y específicos para una misma obra. De igual modo, desde una perspectiva más filosófica, se han abordado las múltiples relaciones teóricas y prácticas entre la autoficción y las literaturas del recuerdo (también conocidas como «narrativas testimoniales» o «novelas testimonio»), estableciendo dife- 
rencias y matices entre conceptos tan esquivos como «verdad», «ficción»y «mentira». Interrogarse sobre la condición de veracidad en textos que emplean mecanismos de la ficción, así como por la «literariedad» de obras en las que la experiencia del daño se expresa sin aparente transformación narrativa ha centrado el trabajo de algunos americanistas, como Gilberto Vásquez (2014) e Ilse Logie (2015), ocupados en discernir los complejos procedimientos y posibilidades de la autoficción para una manifestación de la verdad de lo real pero desde la ficción.

\section{LA AUTOFICCIÓN EN EL CINE Y EL TEATRO}

La proliferación de estudios como los citados pone de relieve el afianzamiento del llamado «giro subjetivo» como tendencia general del arte contemporáneo. En este sentido, el concepto de autoficción puede resultar oportuno - a pesar de su inflación teórica-, pues indica cómo, asumida la imposibilidad de un referente estable, incluido el propio autor, los creadores siguen afanándose en plasmar sus identidades — fragmentaria y precariamente-, con más intensidad incluso que en otros períodos. Una búsqueda instrospectiva que se expresa a través de las experiencias personales como objeto de las obras más allá de la mera inspiración, en la medida en que estas son asumidas como materia novelable o dramatizable. Ello, unido a los procesos, también habituales con mayor frecuencia, de hibridación discursiva (convergencia de distintos géneros; diversificación de las formas de autorrepresentación; problematización de la dualidad factualidad-ficción; inclusión de nuevos soportes y medios), explica en este momento concreto de nuestra historia la emergencia y el desarrollo de los relatos autoficcionales, así como de la bibliografía secundaria que trata de explicar este fenómeno.

Por esa razón, las reflexiones apuntadas pueden resultar también fecundas en otros ámbitos como el cine y el teatro, en los que apenas se ha detenido la teoría de la autoficción. Y, por otro lado, dichos ámbitos (con las particularidades que los caracterizan) plantean nuevos retos para el estudio de la representación ficcional del yo: la identificación problemática entre autor y personaje, así como los procedimientos retóricos específicamente espectaculares, que apelan a la imagen y no solo a la palabra, pueden abrir vías de trabajo poco exploradas hasta ahora. Sin embargo, el estudio de la autoficción aplicada al cine y el teatro debe enfrentarse primero con dos dificultades epistemológicas: en primer lugar, la noción de autoría en medios en los que no resulta sencillo —ni deseable - individualizar la figura del autor, ya que tanto en el cine como en el teatro resulta más apropiado pensar en un autor colectivo que incluya al director, el guionista o autor del texto, los actores, el escenógrafo, el director de fotografía, etc.; y en segundo lugar, la referencialidad de contenido autobiográfico, defendida y negada según el punto de vista que se adopte. 
Con respecto al autor, los escasos trabajos que se ocupan de la autoficción en el cine y el teatro han apuntado algunas soluciones de compromiso: Luz Herrera Zamudio (2007: 36), en la primera tesis doctoral que existe sobre la autoficción en el cine ${ }^{3}$, propone identificar la figura del autor con el guionista y el director; de igual manera, para Vera Toro (2010: 236) el autor en el teatro engloba al director de escena y el escritor responsable del texto dramático.

Por el contrario, Gómez Tarín y Rubio Alcover, en un estudio reciente sobre el narrador fílmico y la autoficción, aplican el término «meganarrador» - que toman de la narratología cinematográfica - en contextos donde esta instancia, además de hacerse manifiesta, experimenta un proceso de personalización, que en determinados casos acaba encarnando figuradamente al autor ${ }^{4}$. José Luis García Barrientos (2009b: 17) delimita, por su parte, la noción de «dramaturgo», un «aparato conceptual (no una persona) ausente que ha visto el drama en lugar (y desde el lugar) del público», y que podríamos comparar con la figura del autor implícito en los textos narrativos. No cabe, pues, confundirlo con el autor de la obra dramática (el escritor) ni con el narrador, que en los textos en prosa sí desempeña una función mediadora entre el autor y el receptor ${ }^{5}$. A partir de estas consideraciones, García Barrientos (2014: 132-133) afirma en un trabajo posterior que el autor, «inequívoco en las escrituras (literatura y cine $)^{6}$, se torna $[. .$.$] problemático en el teatro. ¿Cubre solo al autor del$ texto (cuando lo haya) o también al del espectáculo? — se pregunta- ¿Equivale al "Dramaturgo", término más específico pero también impreciso, o a la suma de este más el Director? ¿Y más el escenógrafo y otros artífices del espectáculo?». Esta última perspectiva deja el problema del autor sin resolver y apunta algunas paradojas a las que me referiré un poco más adelante.

En cuanto a la noción de referencialidad esta también se vuelve conflictiva con respecto a las producciones cinematográficas y teatrales. A partir de las

${ }^{3}$ En fecha reciente, Herrera Zamudio ha publicado su tesis en forma de monografía (2015).

${ }^{4}$ Gómez Tarín y Rubio Alcover (2013: 5) entienden por autor un «"alias" del equipo que produce el texto, y nunca un ente físico individual».

5 «El dramaturgo, a diferencia del narrador, no puede concebirse como delegado de alguien, un autor, que en el teatro no existe. Es el carácter de mediador o intermediario (entre el que de verdad cuenta y lo contado) el que hace del narrador una voz semejante al ojo de la cámara cinematográfica; pero no al dramaturgo, que no realiza trabajo alguno de mediación. El espectador de cine ve por el ojo de la cámara cinematográfica, que es el autor-director; en el teatro, en cambio, es el dramaturgo el que ve por los ojos del público. El titular de la visión dramática es el público. Y el dramaturgo no es, en definitiva, sino el público pensado como anterior a la representación, considerado como responsable, y no como destinatario, de la visión dramática: una especie de autor-implícito construido a partir del público-modelo» (García Barrientos 2009b: 17).

${ }^{6}$ Puede confrontarse esta idea de García Barrientos con la contraria de Gómez Tarín y Rubio Alcover. 
reflexiones de Elisabeth W. Bruss (1980) en torno a la «imposibilidad» del film autobiográfico, por no poder cumplir el cine las condiciones de la autobiografía (en concreto los valores de verdad, acto e identidad) ${ }^{7}$, algunos autores como Efrén Cuevas (2005, 2007 y 2012) o Iván Gómez García (2015 y 2017) han defendido la idea contraria en el marco de la práctica documental que sí tendría por objeto registrar la vida del autor. La fuerza referencial de la imagen resulta, en este sentido, deteminante, ya que el espectador está acostumbrado a identificar dicha imagen "con algo "cierto" y "verdadero"», en especial «cuando el enunciador del relato cinematográfico traslada al espectador la voluntad de autoexpresión...» (Gómez García 2015: 112) ${ }^{8}$. Tanto Cuevas como Gómez aprecian, sin embargo, algunas contradicciones en esta clase de películas, pues «el carácter referencial de la autobiografía resulta aún más patente por el efecto de realidad que provoca el registro audiovisual, al tiempo que su carácter construido es evidenciado por el protagonismo de la mediación subjetiva del cineasta» (Gómez García 2015: 114). Se trata de una paradoja que puede alimentar el concepto de autoficción, en la medida en que los textos autoficcionales, sean del ámbito que sean, tienden a visibilizar los mecanismos de construcción, quebrando de esta manera la ilusión de referencialidad y manifestando abiertamente la autoconciencia del autor. En casos así, la recepción autobiográfica conviviría con la recepción ficticia (Cuevas 2013: 17-18) hasta

7 El valor de verdad («truth-value») permite determinar la veracidad y la sinceridad de la obra autobiográfica (ello se logra comparando el relato en cuestión con otros textos que describen los mismos acontecimientos, así como con lo dicho u escrito por el autor en otras ocasiones); gracias al valor de acto («act-value») la autobiografía se presenta como la exhibición de una acción individual que ejemplifica el carácter o la personalidad del agente responsable de dicha acción; el valor de identidad («identity-value») se explica por la coincidencia de los roles de autor, narrador y protagonista en una única identidad (Bruss 1980: 299-300). En la opinión de esta crítica, dichos valores no pueden expresarse a través del lenguaje cinematográfico: con respecto al valor de verdad, en la mayor parte de los casos la imagen no permite distinguir entre sujetos y predicados (por lo tanto, se hace difícil calibrar la presencia de un punto de vista, de una subjetividad) ni discriminar entre lo esencial y lo accidental (301-302); en cuanto al valor de acto, el cine se debate entre dos clases de obras, las que optan por la representación realista sin apenas marcas personales, y el cine de autor, en el que la cámara subjetiva y los efectos de montaje expresan una personalidad, no obstante, explica Bruss, se trata de «pobres sustitutos» de la subjetividad (306); por último, el valor de identidad no puede cumplirse en el cine, ni tan siquiera en los casos en los que el autor como creador del film aparece «en persona», ya que no es posible estar delante y detrás de la cámara al mismo tiempo (307-308). Los argumentos de Bruss han sido discutidos por no pocos autores, entre ellos Lejeune (2008: 18-22) y Bellour (2009: 287-292).

${ }^{8}$ Cuevas (2012: 107) arguye que Bruss, en su trabajo de 1980, estaba pensando sobre todo en películas de ficción como Otto e mezzo, con protagonistas que funcionan como alter ego del autor. En la opinión de Iván Gómez (2015: 113), Bruss, que murió en 1983, apenas tuvo tiempo de asistir al auge de los documentales autobiográficos, lo que podría explicar en parte su posición al respecto. 
el punto de poder hablar de autoficción cinematográfica ${ }^{9}$ en los términos en que lo hace Iván Gómez a propósito de Mapa (2012), de Elías León Siminiani, un documental en el que el discurso autobiográfico aparece combinado con elementos que provienen del terreno de la ficción, en particular la estructura del propio film: una historia de amor y desamor que dota a la película de «progresión dramática y coherencia narrativa» (Gómez García 2015: 113), además de superponer al relato personal, autobiográfico, algunas de las convenciones del cine de imaginación ${ }^{10}$.

Otros autores, en cambio, llegan al campo de la autoficción siguiendo un camino inverso: de acuerdo con Bruss, y su negativa de asumir la referencialidad autobiográfica en el cine, algunos trabajos adoptan la noción de autoficción porque esta subraya precisamente el no autobiografismo cinematográfico y la inevitable tendencia de este medio a la ficcionalidad. Gómez Tarín y Rubio Alcover asumen, por ejemplo, los presupuestos deconstruccionistas según los cuales la distinción entre autobiografía y ficción es indecidible (De Man 1991) al compartir ambas formas la retoricidad del lenguaje (en las dos es tropo, metáfora, desplazamiento), de manera que el yo es reemplazado por su (des) figura y el cuerpo del texto es una máscara que sustituye como la prosopopeya a la persona convocada. Desde esta óptica, la verdad autobiográfica no sería predicable fuera del lenguaje que (des)figura su voz. Gómez Tarín y Rubio Alcover (2013: 13) explican dicha indecidibilidad por el proceso de selección de los materiales que conforman la película — queda fuera de plano lo que no se quiere mostrar-, así como por la elección de un particular punto de vista que es el que determina la perspectiva desde la que se muestran los acontecimientos narrados. En ese aspecto no habría diferencia entre una película supuestamente autobiográfica y otra que no lo fuera.

Para Herrera Zamudio (2007: 72) simplemente la forma dialogada de un film, así como los efectos del montaje — que ella divide en efectos de enlace y de disyunción-funcionan como indicadores ficcionales.

En el teatro también se ha negado a menudo la posibilidad de la autobiografía. García Barrientos (2009a: 93) atribuye esta imposibilidad al carácter inmediato de la representación teatral que, como explica Aristóteles, es inherente al modo de imitación dramático: en él no concurre mediación alguna, como sí sucede en la representación narrativa - dentro de la que García Barrientos incluye al cine-, de naturaleza mediada, donde la voz del narrador o

9 Aunque Efrén Cuevas no llega a emplear este concepto. Sí lo utiliza Agustín Gómez Gómez (2014), aplicándolo a algunos títulos de Pedro Almodóvar.

${ }^{10}$ En un trabajo prácticamente simultáneo al de Iván Gómez, Agustín Gómez Gómez (2015) analiza Mapa también desde la teoría de la autoficción, al entender que «el autor se inscribe en la película asumiendo una enunciación directa, no delegada, en un formato que pretende ser documental pero que contiene numerosas rupturas con la idea de no ficción» (364). 
el ojo de la cámara son las instancias mediadoras. Desde este punto de vista, la autobiografía solo podría ser narrativa, al tratarse de «la representación de una vida (biografía) 'hecha por' esa misma persona (auto)» y exigir, en consecuencia, la mediación de un narrador (García Barrientos 2009a: 94). En fecha reciente este mismo teórico ha afirmado todavía de manera más contundente que, mientras que la narración puede ser ficticia o factual, «el teatro es ficción y solo ficción»:

... que tal disimetría tiene relación con el modo lo prueba quizás que el documental cinematográfico no tenga equivalente en el teatro (verdadero, no sucedáneo, como el llamado "teatro documento"), igual que no lo tienen la historia o la biografía genuinas. Se diría que el teatro contagia cuanto toca o cuanto por él pasa de ficcion. De ahí la doble imposibilidad de un teatro autobiográfico: por auto- y por factual (García Barrientos 2014: 129).

Se trata de una idea extendida entre los estudiosos del drama. En esta línea, Beatriz Trastoy (2006: 2), en sus trabajos en torno al teatro unipersonal, entiende que «sobre la escena, todo es (o parece) ficción» ${ }^{11}$; Julia Elena Sagaseta (2006: 1) afirma, por su parte, que «es difícil pensar en teatro en una biografía o en una autobiografía que eluda algún elemento ficcional» ${ }^{12}$; y la dramaturga y promotora del proyecto «Biodrama» ${ }^{13}$ Vivi Tellas considera que «lo documental es propio del cine, pero cuando se vincula con el teatro fracasa porque, por su misma estructura, el teatro transforma todo en ficción inmediatamente» (Tellas en Blejmar 2010: s/p). En este sentido, la autoficción puede ser —otra vez en la opinión de García Barrientos (2014: 129) — «una salida (aunque sea por la tangente) a la aporía del drama autobiográfico».

\section{Perspectivas DE ANÁLISIS}

Como puede apreciarse, el teatro y el cine, por sus propias singularidades, pueden abrir sugerentes reflexiones en torno al concepto de autor y sus complejas implicaciones en la modulación autoficcional en campos distintos al li-

${ }^{11}$ Lo argumenta del siguiente modo: «el testimonio de vida, narrado frente a las cámaras de televisión en un espacio considerado periodístico, resulta mas creíble que si esa misma historia es relatada por la misma persona desde un escenario a los espectadores presentes. Asimismo, es más fácil considerar auténtica la autobiografía contada por un individuo ajeno a la práctica escénica que la narrada por un actor o actriz, siempre asociado a la impostura que supone representar personajes reales» (Trastoy 2006: 2).

12 En este mismo trabajo sobre las formas biográficas en el teatro, Sagaseta (2006: 6) llega a preguntarse: «¿Acaso la escena no es ya una marca de ficción, de teatralidad...?».

${ }_{13}$ El proyecto «Biodrama», cuyo objeto era representar vidas verdaderas en el escenario, se desarrolló en el Teatro Sarmiento de Buenos Aires del año 2002 al año 2009. 
terario, donde sí hay un cierto consenso en asimilar al autor con una única persona real, empírica, que es la que firma la portada. El problema de la referencialidad presenta otras dificultades: las manifestaciones cinematográficas y teatrales calificadas de autoficciones escenifican las tensiones entre factualidad y ficción de un modo, si cabe, más radical que los textos narrativos. La potencia de las imágenes - poseedoras de esa fuerza referencial a la que ya me he referido-, así como la configuración del cuerpo vivo del actor en significante y significado, funcionan como un marco de referencia que puede ser asaltado por diversos elementos disruptivos (metalepsis y mise en abyme, inverosimilitudes, distorsión humorística y/o fantástica), rompiendo de manera eficaz con la transparencia del lenguaje mimético y, por ende, con la ilusión autobiográfica. Esta sería, a mi modo de ver, la característica fundamental que definiría la autoficción tanto en el cine como en el teatro: la voluntad de deconstruir el yo autorial proyectado en la obra. Aunque, como apunta Fernando Cabo (2014: 30) con relación a la autoficción en narrativa, detrás de todos estos debates laten otros de mayor calado y antigüedad: autoría, referencialidad, ficción, escritura, performatividad, son nociones complejas que pueden ser consideradas a la luz de productos híbridos o «problemáticos» como los que estudian los autores citados.

El establecimiento del corpus depende, no obstante, de la perspectiva de análisis que se privilegie. De manera parecida a lo que observaba al principio de este trabajo con respecto a los estudios en torno a la narrativa autoficcional, los análisis de cine y teatro ponen el acento bien en obras con un fuerte anclaje referencial (cine documental, teatro-documento) donde los mecanismos de hibridación propician un pacto contradictorio y problematizan la recepción; o bien en obras, en las que la figura del autor (identificada con alguna de las instancias emisoras, principalmente el guionista/dramaturgo, el director o los actores) se proyecta ficcionalmente en la pantalla o en el escenario. Trataré a continuación de sintetizar ambas posiciones.

\section{a) En el cine}

Con relación a las manifestaciones cinematográficas cercanas a la no ficción o a la autobiografía son pocos los autores que han aplicado la teoría de la autoficción o se han referido a ella, y esto a pesar de las abundantes consideraciones en torno a un cierto tipo de cine de no ficción que aúna performatividad, autorretrato y elementos ficcionales. Los trabajos de Laia Quílez (2009) sobre el documental performativo y Mario de la Torre (2015) sobre el documental español actual son, junto a los ya mencionados de Iván Gómez (2015 y 2017), algunas de esas pocas excepciones. Estos tres críticos coinciden en señalar el documental - especialmente el diario filmado, la crónica familiar y el cine-ensayo - como el modelo sobre el que opera la autoficción audiovisual, 
entendida como desvío o variante experimental de la autobiografía cinematográfica $^{14}$. A propósito señala Iván Gómez (2017) cómo el documental, en tanto que espacio de la «verdad» — de los hechos verídicamente comprobables —, se transforma, a partir de los años 60 y de manera progresiva, en «un discurso abierto y en perpetua mutación, receptivo también al Yo como un elemento posible - y problemático - del marco enunciativo». Dicha presencia cada vez más frecuente - la de este Yo, que a menudo podemos identificar con el director y que también suele aparecer en la pantalla-, no solo imprime singularidad a lo narrado, sino que expresa, en no pocas ocasiones, una conciencia de lo autobiográfico como algo construido ${ }^{15}$. Como señala Mario de la Torre (2015), determinados factores de orden formal - el uso emotivo de la banda sonora; los efectos del montaje, como el empleo del raccord, la aceleración o desaceleración de imágenes, las omisiones patentes; o incluso algunos mecanismos de simbolización - generan una evidente distancia entre el yo fílmico y el yo autobiográfico; distancia que caracteriza la modulación autoficcional en algunos documentales híbridos, como los de Mercedes Álvarez, José Luis Guerín o Juan Barrero.

El estudio de la autoficción aplicado a obras claramente ficcionales ha tenido más recorrido, aunque no ha sido definido de manera unívoca ${ }^{16}$. Para Luz Herrera Zamudio, que adapta al cine el esquema de Vincent Colonna con respecto a la novela, la autoficción se establece a partir de tres «posturas» o modalidades: la biográfica, que ejemplifica con Caro diario (1993), de Nanni Moretti; la especular, con Husbands and wives (1992), de Woody Allen; y la fantástica, con Léolo (1992), de Jean-Claude Lauzon ${ }^{17}$. En las tres intervienen, por un lado, el protocolo de identidad entre personaje y autor, y, por el otro, el protocolo modal. El primero se expresa a través de la coincidencia del nombre

14 Para Efrén Cuevas (2005: 222), «la autobiografía fílmica encuentra su hábitat natural en la práctica documental, pues solo ahí se puede hablar en sentido estricto de registro autobiográfico».

${ }^{15}$ Así, para Quílez (2009: 118, n. 3), la performación en cierto tipo de films — de Avi Mograbi, Ross McElwee o Alan Berliner, por ejemplo- «acercaría a estos documentales marcadamente homodiegéticos al terreno de lo que Serge Doubrovsky bautizó en 1977 y en el ámbito de la literatura como autoficción». Ya había empleado el término en un artículo anterior (Quílez 2008: 89), en esa ocasión, para caracterizar Los rubios (2003), de Albertina Carri.

${ }^{16}$ Esto es así dada la amplitud de la propia noción de autoficción, una «forma narrativa algo esquiva que puede aparecer en las prácticas documentales híbridas o en determinadas ficciones que apelan a la autenticidad de parte de lo que cuentan» (Gómez García 2017).

${ }_{17}$ Herrera Zamudio deja fuera de su tesis el estudio de la autoficción intrusiva o autorial, la cuarta postura señalada por Colonna en su libro de 2004. En este caso «el avatar del escritor es un recitador, un relatador o un comentarista, en resumen: un "narrador-autor" al margen de la trama» (Colonna 2012: 115). Por ello, resulta difícilmente trasladable a la pantalla. 
del personaje y del autor, que puede aparecer completo, transformado o cifrado, así como a través de la coincidencia de la imagen de ambos (incluyendo los modos de identificación indirectos y alusivos ${ }^{18}$. Una vez establecida la identidad entre autor y personaje, el protocolo modal — los rasgos sintácticos, semánticos y pragmáticos del film - debe afirmar la ficcionalidad de la obra: así, la escenificación de las palabras y deseos de Nanni Moretti, en Caro diario, cuando, tras expresar su fascinación por Flash Dance, se encuentra en la calle «por casualidad» con Jennifer Beals, la actriz que en su día protagonizó esa película (rasgo sintáctico); la inclusión de escenas oníricas y fantásticas en Léolo (rasgo semántico); o el empleo de la técnica documental en Husbands and wives con el objeto de transgredir la supuesta factualidad de este soporte por medio de la ficción (rasgo pragmático).

Gómez Tarín y Rubio Alcover restringen algo más el concepto de autoficción, al circunscribirlo al relato autodiegético, en el que el ente enunciador se materializa físicamente (en voz o en cuerpo), adoptando los rasgos del realizador (como la parte más visible del autor colectivo). La historia - que discursivamente tiene que ser una ficción — debe estar sometida a ese único punto de vista. Bajo estas condiciones, «la autoficción no será otra cosa que la representación diegetizada de una historia vinculada a tal procedimiento enunciador» (Gómez y Rubio 2013: 14) ${ }^{19}$. Con estas premisas, films como Adaptation (Spike Jones 2002) o series como ¿Qué fue de Jorge Sanz? (David Trueba 2010) serían solo «autoficciones simuladas»: la primera utiliza «personajes reales para hacer reflexiones sobre el guion desde una enunciación que finge ser la misma que le corresponde al ente enunciador»; y la segunda presenta un protagonista que, aunque caricaturiza a una persona real, es sobre todo un personaje de ficción «en el seno de una historia que nada tiene que ver con su realidad cotidiana» (ibíd.: 21-22).

Apunto esta última posibilidad porque la idea que hay detrás de la autoficción simulada recuerda a la del «autor representado» tal y como lo define José Antonio Pérez Bowie. Aunque para este crítico el sintagma recubre la figuración del libro adaptado o del guionista — como en el caso de Adaptation-, también podría dar cabida a la figuración del actor, si admitimos el papel

${ }^{18}$ Las opciones que se derivan son variadas: a) un autor interpreta a un personaje con el que comparte el nombre o un derivado del nombre (Nanni Moretti en Caro diario); b) un actor comparte el nombre o un derivado de ese nombre con el autor o varios rasgos de la imagen de aquel (Marcello Mastroianni interpretando a Guido Anselmi, trasunto de Federico Fellini en Otto e mezzo, 1963); c) un autor interpreta a un personaje que no se llama como él pero se le parece en varios aspectos (Woody Allen interpertando a Sandy Bates en Stardust Memories, 1980). Véase Herrera Zamudio (2007: 54).

${ }^{19}$ Más adelante: «Cuando el propio autor se inscribe en la historia con su presencia física, asumiento la enunciación directa (no delegada) y el formato es el de la fícción o, cuando menos, la nebulosa frontera entre ficción y no-ficción, estamos en condiciones de calificar el texto como autoficción» (Gómez Tarín y Rubio Alcover 2013: 17-18). 
co-creador (por lo tanto autorial) de los actores (Pérez Bowie 2013: 66-67). De hecho, la definición que da Pérez Bowie de la autoficción es todavía más restrictiva que la que ofrecen Gómez Tarín y Rubio Alcover, ya que solo la aplica a películas en las que «el propio director puede aparecer [...] como intérprete encarnando dentro de una historia de ficción (pero con innegable base autobiográfica) a un director que presenta evidentes similitudes con el personaje real», como ocurre, por ejemplo, en La nuit americaine (1973), de François Truffaut o Stardust Memories, de Woody Allen (57). La mención de la autoficción tiene lugar aquí en un contexto muy preciso: es una de las variantes del narrador personalizado en aquellos casos en los que la instancia narradora pierde su invisibilidad habitual. La voz over (extradiegética), la presencia del director en el filme-ensayo, el director ficcionalizado (que en otras definiciones menos acotadas que la de Pérez Bowie también podría acercarse a la noción de autoficción $)^{20}$, son otras posibilidades.

\section{b) En el teatro}

En los estudios teatrales, la perspectiva adoptada en la mayor parte de los trabajos también se decanta por la línea de la ficción. Pese a ello, algunos textos emprenden el estudio de las formas híbridas que presentan un grado importante de factualidad. En su trabajo de 2014, García Barrientos menciona el espectáculo unipersonal —en el que coinciden actor, personaje y autor del texto y de la puesta en escena-, el monólogo cómico y las formas del performance, aunque apenas se detiene en ellos. Entre las cinco posibilidades autoficcionales que Vera Toro contempla en su estudio, y sobre la base de la identificación Autor (director y escritor) $=$ Actor $=$ Personaje, una de esas modalidades - Autoficción III en el esquema de Toro- pondría el acento en su relación con el referente: «El autor real (a veces como director o guionista) interpreta a un personaje con el cual comparte el nombre o un derivado $\mathrm{y} / \mathrm{u}$ otros rasgos de su biografía» (Toro 2010: 238); sería el llamado «teatro autobiográfico» según la conceptualización de Trastoy (2002), de quien Toro toma algunos ejemplos, como Tutta casa letto e chiesa (1984), de Franca Rame y Dario Fo, Nacha de noche (1985), de Alberto Favero y Nacha Guevara, y La Campoy en vivo (1994), interpretado por Ana María Campoy y escrito y dirigido por Pepe Cibrián Campoy ${ }^{21}$. Por su parte, para Mario de la Torre (2014: 57)

20 El director ficcionalizado aparece «en filmes que se presentan como una reflexión personal del director con componentes autobiográficos del director real, que es interpretado por un actor» (Pérez Bowie 2013: 56).

21 En España, hace algunos pocos años, se llevó a cabo el musical autobiográfico Concha... Yo lo que quiero es bailar (2011), dirigido por Josep Maria Pou, y escrita por José María Pou, Concha Velasco y Juan Carlos Rubio. 
es condición sine qua non de la autoficción teatral la coincidencia plena entre autor dramático, director de escena, actor y personaje, pues dicha identidad, como sucede en buena parte de la dramaturgia de Angélica Liddell —que es objeto de su estudio - , introduce al espectador «en un estado de incertidumbre, al no poder distinguir si lo observado tiene referencialidad en el mundo real o bien si ha sido creado para su representación escénica».

De igual modo, y con respecto a las relaciones entre autoficción y referencialidad, los trabajos de Anxo Abuín y de Mauricio Tossi ofrecen elementos de interés para el análisis. El primero acuña la noción «autoficción posdramática» (Abuín 2011: 158-161), identificándola con una línea sobresaliente del teatro posmoderno, que, caracterizado por la mezcla de lenguajes formales, la densidad intermedial, la corporalidad o la interacción con el espectador (ibíd.: 165), emplea a menudo abudante material autobiográfico - habitualmente del actor, que suele coincidir con el director teatral ${ }^{22}$ - Como ocurre en los espectáculos de Liddell, a la que Abuín dedica buena parte de su estudio, la fuerte carga referencial - la exhibición directa de la vida de la actriz - se combina con una impactante exageración de los dispositivos de representación del yo - histrionismo, autolesión, repetición de acciones, etc.- .

Tossi (2015: 98), por su parte, opta por otro concepto, «autoficción performática», que, en el contexto del teatro argentino de la posdictadura, aplica al docudrama. Dicha noción cobra toda su relevancia en obras en las que «el documento histórico presentado en escena es el cuerpo vivo del actor» (93), como sucede en Mi vida después, de Lola Arias: la pieza reúne a seis actores nacidos en los 70 - hijos de desaparecidos, represaliados y hasta de un policía de la Secreta - que reconstruyen sobre la escena la vida de sus padres, a la vez que narran sus vivencias como «hijos» a partir de su memoria y de su propia biografía. Para Tossi la autoficción performática sería, «quizás, la única modalidad posible de reconocer [la autoficción] en el arte teatral» (106), una propuesta que, me parece, podría arrojar luz sobre la autoficción en el teatro y, también en el cine, al poner el acento en el cuerpo del actor como referente sostenido - gracias a la interdiscursividad entre el cuerpo y el documento autobiográfico - y, simultáneamente, como signo autorreferencial — gracias a la identificación plena entre dramaturgo, actor y personaje, y al desmantelamiento de ese yo omnímodo a través de distintos mecanismos espectaculares_ ${ }^{23}$. Como demuestra en un trabajo posterior, la práctica del cuerpo del

22 Abuín (2011: 161-162) pone como ejemplos los espectáculos de Marina Abramovič, Allan Kaprow, Spalding Gray o, en la escena española, Angelica Liddell.

${ }^{23}$ Tomo algunas ideas de Mauricio Tossi desplegadas en su exposición «Docudrama y autoficción teatral: revisión teórica y reconocimiento de problemáticas», dentro del Workshop internacional «La autoficción hispánica (1980-2013). Perspectivas interdisciplinarias y transmediales», que tuvo lugar los días 20 y 21 de enero de 2015 en la Facultad de Filosofía y Letras de la Universidad de Alcalá. 
actor — reconocida sobre todo a partir de principios del siglo $\mathrm{XX}$ - hace que este se constituya en una entidad sígnica que favorece la expresión del yo.

Al tener en cuenta aspectos específicamente espectaculares, las perspectivas adoptadas por Abuín y Tossi abren una importante vía de reflexión, que desafía otras conceptualizaciones más tradicionales, como la de Vera Toro (2010: 237, n. 17), para quien que «el autor real pueda aparecer corporalmente en una representación teatral es limitado a la duración de la vida de este autor». Las propuestas de Abuín y Tossi, al contrario, intuyen posibilidades en esa misma fugacidad, que, por otro lado, es característica del hecho teatral en sí mismo.

Por último, cabe citar de nuevo los trabajos de Vera Toro y de García Barrientos, en los que el teatro autoficcional se vincula a expresiones en las que la tensión ficción-factualidad se resuelve a favor de la primera. Así, Toro (2010: 237-238) lleva a cabo una categorización de las distintas modalidades autoficcionales: además de la ya mencionada Autoficción III, distingue la Autoficción I, cuando «el autor comparte el nombre o un derivado con un personaje interpretado por otro actor», por ejemplo, El álbum familiar (1982), de José Luis Alonso de Santos; la Autoficción II, cuando «el autor no comparte el nombre, sino otros rasgos de su identidad (descritos en las acotaciones) con un personaje interpretado por otro actor», por ejemplo, Los viejos, diálogo imprevisto en un acto (1971), de Rodolfo Usigli, o también el personaje de Max Estrella como trasunto de Valle-Inclán, sobre todo en la célebre escena XII; un caso teóricamente posible pero con escasa operatividad, cuando «el nombre del autor $\mathrm{u}$ otra obra del autor son meramente mencionados por el hablante extradiegético heterodiegético (en las acotaciones)»; y la Autorficción, cuando tiene lugar «una breve intromisión del autor en su obra, no necesariamente como personaje», que Toro equipara con la metalepsis del autor, por ejemplo en Seis personajes en busca de autor (1925), de Luigi Pirandello.

Por su parte, José Luis García Barrientos (2009b) acomete el análisis de El público [1933], de Federico García Lorca, El álbum familiar, de Alonso de Santos, Nunca estuviste tan adorable (2004), de Javier Daulte, y, en su trabajo de 2014, de Tebas Land (2013), de Sergio Blanco, obras en las que se dejan oír con fuerza los ecos referenciales - las experiencias vitales de sus creadores- pero siempre desde la ficción. Ello nos devuelve al punto de partida ontológico de García Barrientos, para quien la existencia de un autor colectivo junto con la presencia del cuerpo del (autor-)actor como signo escénico (en consecuencia, fingido, ficcional) hacen que en el teatro lo autobiográfico se incline de manera natural hacia la ficción. Las obras mencionadas profundizarían en la paradoja de presentar una identidad aproximada entre autor y personaje y la inevitable ficcionalización de los elementos que se ven involucrados en el espectáculo teatral, pues, sobre el eje realidad-ficción, el actor se desdobla — en su caso en personaje-, del mismo modo que también se desdoblan el espacio, el tiempo y el público. 


\section{CONCLUSIONES}

Como ha podido observarse, algunos trabajos sobre la autoficción en el cine y el teatro aluden a la evolución de la práctica actoral como parte del fenómeno. Efectivamente, en la escena y el cine contemporáneos, el cuerpo del actor posee una insoslayable potencialidad creativa, en la medida que «corporeiza» - más que «encarna»- un personaje con el que se identifica, aun de forma problemática (Tossi 2017). Consecuentemente, en la autorrepresentación audiovisual tiene lugar, como advierte Julio Prieto (2017), «una ficcionalización del cuerpo, $[. .$.$] de la figura física del autor-actor que pone en escena o en panta-$ lla un "personaje yoico"». Es lo que sucede, por poner un ejemplo del cine, en la película L'enlèvement de Michel Houellebecq (2014), protagonizada por dicho escritor francés, como si participara en un documental sobre su persona ${ }^{24}$. Escrita y dirigida por Guillaume Nicloux, el film se interroga, en realidad, por las complejas - y a veces tensas - relaciones entre el escritor y la crítica, los lectores y los medios de comunicación a través de la figura - $\mathrm{y}$, por lo tanto, del cuerpo- de Houellebecq. Subyace, así, una reflexión nada inocente sobre «la postura de autor» a través de la hábil combinación de factualidad — con respecto a la cual el propio Houellebecq lleva el mayor peso, en tanto que personaje y actor - y ficción disparatada, ya que la película ofrece una muy poco plausible explicación a su «desaparición», cuando, tras ganar el Premio Goncourt con la novela La carte et le territoire (2010), dejó plantados a los organizadores de su gira literaria en los Países Bajos. Una ausencia que, en el momento, generó todo tipo de especulaciones acerca de su paradero y que Nicloux - con la complicidad de Houellebecq, que inevitablemente tiene un papel co-creador en la obra- convierte en un divertido relato sobre la persona del escritor: durante su secuestro a manos de delincuentes a sueldo nunca sabremos exactamente de quién - aunque llega a insinuarse que detrás de la operación bien pudiera estar el mismísmo Presidente de la República, François Hollande-, Houellebecq se presenta con el mismo aspecto desaliñado que luce últimamente - despenaido y sin dientes - , practicando sexo con una prostituta, fumando compulsivamente, bebiendo más de la cuenta y, cómo no, vertiendo algunas de sus opiniones más controvertidas sobre política o sobre el mundillo literario. Es decir, hiperboliza rasgos de su personalidad, costumbres, ideas, con el fin de alimentar su consabida fama de «énfant terrible» de las letras francesas, a la vez que se ríe de ella, llevando al extremo el sentido último de la autoficción: «Tout est faux dans ma biographie», afirma en un momento de la cinta, como falsa, o exagerada, o poco fiel a la realidad, es la imagen, podemos pensar, que los críticos, los medios de comunicación, pero

\footnotetext{
${ }^{24}$ Se trata de una película en clave de comedia cuya forma integra elementos del documental, apreciables sobre todo en el movimiento de la cámara.
} 
también el propio escritor con sus declaraciones y, en particular, con las ideas que reflejan sus novelas, han contribuido a generar sobre él.

De las obras comentadas - los estudios académicos y los textos de creación-, se deduce que el concepto de autoficción, a pesar de su fuerte arraigo en el campo de la narrativa, puede resultar operativo también en los estudios cinematográficos y teatrales. Permite ahondar en la reflexión en torno a la autoría y a la referencialidad, destacando los problemas y las paradojas que estas nociones plantean desde el punto de vista teórico. Por un lado, la autoficción contribuye a poner de manifiesto las tensiones que anidan en el concepto de autor en artes como el cine y el teatro, en las que no es posible identificar de manera neta, no problemática, esta figura con una única persona. Podemos preguntarnos incluso en qué medida la autoficción en estos dos medios no está precisamente explorado dicha dificultad, no la está llevando al límite: la práctica autoconsciente que esta implica cuestiona, en efecto, nociones ingenuas en torno a la representación del autor, en especial la unidad del sujeto (en la vertiente personal e identitaria del yo) y la originalidad del artista (en la vertiente creativa del yo). Películas, entre las citadas, como Otto e mezzo o su reescritura Stardust Memories, o Caro diario, y obras teatrales como El público o Tebas Land profundizan en todas estas contradicciones. Lo hacen obviamente empleando los recursos que están a su alcance y que son los propios de los medios cinematográfico y teatral: una determinada caracterización del personaje-autor (en Adaptation, por ejemplo, el actor Nicolas Cage aparece caracterizado con los rasgos, incluidos los más caricaturescos, del guionista-persona real Charlie Kaufman), el desdoblamiento del autor en varios personajes encarnados por un mismo actor o por distintos actores (los diversos Directores que aparecen en El público), la distorsión humorística o el distanciamiento brechtiano como técnicas actorales (Mi vida después), la autolesión en escena (las obras de Angélica Liddell), etc.

Por otro lado, la figuración del yo tensiona también el carácter referencial de los films y las obras en los que esta aparece. El foco puesto sobre el «autor» -ya sea el director, el guionista, el dramaturgo o un actor: cualquier manifestación visible, por lo tanto, de una de las facetas del autor- revela en estos casos que la personalidad que identificamos con el autor no es más que el fruto de una construcción ficcional llevada a cabo a propósito. De ahí el sentido de algunos experimentos que desafían las convenciones que rigen el lenguaje cinematográfico y el lenguaje teatral: el empleo de la metalepsis y la mise en abyme (Caro diario, Stardust Memories), el uso de una matriz intertextual (Mapa) o la utilización de distintos recursos que cuestionan la contigüidad mundo-escena (las fotografías de los padres proyectadas en el cuerpo de los hijos en Mi vida después).

Lo performativo, la «inscripción del "yo" en un cuerpo o, en ausencia, en una mirada sobre el mundo» — —en palabras, de Alain Bergala (2008: 32) — es una de las novedades que plantea la autoficción filmada con respecto a la es- 
critura autobiográfica. La presencia de un rostro, que podemos identificar directa o indirectamente con una de las instancias emisoras - el director, el guionista, incluso el actor-, invita al espectador a cobrar conciencia de la máscara antes que de la persona, del discurso en torno al yo antes que de su referente. También las dramaturgias experimentales en esta línea se afanan en desmontar la ilusión autobiográfica: borrando las fronteras entre ficción y verdad, el cuerpo del actor se convierte en ese «espacio de duda y subversión» (Abuín 2011: 166) que desestabiliza el carácter enunciador de todo texto, incluido el cinematógrafico y teatral. Hablar del yo sin exponer la propia autobiografía - afirmando y negando a la vez la referencialidad del sujeto a través de la parodia, la hipérbole o lo sacrificial - es una de las premisas centrales en todas estas obras.

\section{BIBLIOGRAFÍA CITADA}

Abuín González, Anxo (2011). «Poetry and Autofiction in the Performative "Field of Action": Angélica Liddell's Theater of Passion», en Cornelia Gräbner y Arturo Casas (eds.), Performing Poetry: Body, Place and Rhythm in the Poetry Performance. Amsterdam: Rodopi, pp. 151-172.

Alberca, Manuel (2007). El pacto ambiguo. De la novela autobiográfica a la autoficción. Madrid: Biblioteca Nueva.

Bellour, Raymond (2009). Entre imágenes. Foto. Cine. Video [2002]. Buenos Aires: Coliure.

Bergala, Alain (2008). «Si "yo" me fuera contado» [1998], en Gregorio Martín Gutiérrez (ed.), Cineastas frente al espejo. Madrid: T\&B Editores, pp. 27-33.

Blejmar, Jordana (2010). «Reescrituras del yo. Apuntes sobre Mi vida después de Lola Arias», Afuera. Revista de crítica cultural. 8, s/p. Disponible en $<\mathrm{http} / / / \mathrm{www} . r e v i s t a a f u e r a$. com/articulo.php?id=79\&nro=8> [última visita: 25.01 .2015 ].

Bruss, Elisabeth W. (1980). «Eye for I: Making and unmaking autobiography in film», en James Oleny (ed.), Autobiography: Essays theoretical and critical. Princeton: Princenton University Press, pp. 296-320.

Cabo, Fernando (2014): «Teatralidad, itinerancia y lectura: sobre la tradición teórica de la autoficción», en Ana Casas (ed.), El yo fabulado. Nuevas aproximaciones críticas a la autoficción. Madrid-Frankfurt: Iberoamericana-Vervuert, pp. 25-43.

Colonna, Vicent (1989). L'autofiction. Essai sur la fictionalisation de soi en littérature. Lille: ANRT (microfiches n. ${ }^{\circ} 5650$ ).

Colonna, Vicent (2004). Autofiction \& autres mythomanies littéraires. Auch: Tristam.

Colonna, Vicent (2012). «Cuatro propuestas y tres deserciones (Tipologías de la autoficción)», en Ana Casas (ed.), La autoficción. Reflexiones teóricas. Madrid: Arco Libros, pp. 85-122.

Cuevas, Efrén (2005). «Diálogo entre el documental y la vanguardia en clave autobiográfica», en Casimiro Torreiro y Josetxo Cerdán (eds.), Documental y vanguardia. Madrid: Cátedra, pp. 219-250. 
Cuevas, Efrén (2007). «Esculpir el yo: la autobiografía según Ross McElwee», en Efrén Cuevas y Alberto N. García (eds.), Paisajes del yo. El cine de Ross McElwee. Madrid: Ediciones Internacionales Universitarias, pp. 37-69.

Cuevas, Efrén (2012). «El cine autobiográfico en España: una panorámica», Rilce. Revista de Filología Hispánica. 28 (2), pp. 106-125.

Cuevas, Efrén (2013). «Fronteras del yo en el documental español contemporáneo», en Norberto Míngez (ed.), Ficción y no ficción en los discursos creativos de la cultura española. Madrid -Frankfurt: Iberoamericana -Vervuert, pp. 115-128.

Decock, Pablo (2014). Las figuras paradójicas de César Aira. Un estudio semiótico y axiológico de la esterotipia y la autofiguración. Berna-Oxford: Peter Lang.

Decock, Pablo (2015). «El simulacro de la desidentidad: las figuras autoriales en el espacio autoficcional de Aira y Vila-Matas», Pasavento. Revista de estudios hispánicos. III (1), pp. $15-28$.

De la Torre, Mario (2014). «Rupturas del pacto escénico: narrativa y discurso en el teatro de Angélica Liddell», Telón de fondo. Revista de teoría y crítica teatral. 20, pp. 53-67. Disponible en <http://www.telondefondo.org/numero20/articulo/532/rupturas-del-pactoescenico-narrativa-y-discurso-en-el-teatro-de-angelica-liddell.html $>$ [última consulta: 27.05.2015].

De la Torre, Mario (2015). «Cines del yo: el documental autoficcional contemporáneo español», Bulletin of Hispanic Studies. 92 (5), pp. 567-582. https://doi.org/10.3828/ bhs.2015.33

De Man, Paul (1991). «La autobiografía como desfiguración» [1979], Suplementos Anthropos. 29, pp. 113-118.

Doubrovsky, Serge (1977). Fils. París: Galilée.

García Barrientos, José Luis (2009a). «(Im)posibilidades del drama autobiográfico (El álbum familiar y Nunca estuviste tan adorable)», en Osvaldo Pellettieri (ed.), En torno a la convención y a la novedad. Buenos Aires: Galerna, pp. 93-104.

García Barrientos, José Luis (2009b). «El autor y el público en la ficción teatral: Paradojas de la ausencia y la presencia», en Mariela de la Torre, Victoria Béguelin-Argimón y Rolf Eberenz (eds.), Sobre tablas y entre bastidores: Acercamientos al teatro español. Homenaje al profesor Antonio Lara Pozuelo. Madrid: Biblioteca Nueva, pp. 15-34.

García Barrientos, José Luis (2014). «Paradojas de la autoficción dramática», en Ana Casas (ed.), El yo fabulado. Nuevas aproximaciones críticas a la autoficción. Madrid-Frankfurt: Iberoamericana-Vervuert, pp. 127-146.

Gómez, Sonia (2015). «Juegos autoficcionales en la obra de Manuel Vilas», Pasavento. Revista de estudios hispánicos. III (1), pp. 155-169. Disponible en <http://www.pasavento. com/pdf/05_11_gomez.pdf> [última consulta: 10.11.2015].

Gómez García, Iván (2015). «Mapa(s) sin territorio: un paseo por la autoficción de Elías León Siminiani», Pasavento. Revista de estudios hispánicos. III (1), pp. 109-122. Disponible en <http://www.pasavento.com/pdf/05_08_gomez.pdf> [última consulta: 10.11.2015].

Gómez García, Iván (2017). «Espejos audiovisuales. Autofiguraciones del yo en el cine contemporáneo», en Ana Casas (ed.), El autor a escena. Intermedialidad y autoficción. Madrid-Frankfurt: Iberoamericana-Vervuert, pp. 13-38.

Gómez Gómez, Agustín (2014). «Del autorretrato a una cierta autobiografía», en Pedro Poyato Sánchez (ed.), El cine de Almodóvar: una poética de lo "trans". Sevilla: Universidad Internacional de Andalucía, pp. 55-84. 
Gómez Gómez, Agustín (2015). «La transparencia de un diario audiovisual de ficción: Mapa (2012), de Elías León Siminiani», Signa. Revista de la Asociación Española de Semiótica. 24, pp. 361-374. https://doi.org/10.5944/signa.vol24.2015.14712

Gómez Tarín, Francisco Javier y Agustín Rubio Alcover (2013). «Narrador fílmico y autoficción. Nuevas posibilidades del punto de vista», en Actas del V Congreso Internacional Latina de Comunicación Social. Universidad de La Laguna, pp. 1-28. Disponible en <http://www.revistalatinacs.org/13SLCS/2013_actas/033_Gomez.pdf $>$ [última visita: 17.01.2015].

Herrera Zamudio, Luz Elena (2007). La autoficción en el cine. Una propuesta de definición basada en el modo analítico de Vincent Colonna. Universidad Autónoma de Madrid, tesis de doctorado. Disponible en $<$ https://repositorio.uam.es/handle/10486/1680> [última visita: 17.01.2015]. Publicada posteriormente como monografía (2015). Saarbrücken: Publicia.

Lejeune, Philippe (2008). «Cine y autobiografía, problemas de vocabulario» [1998], en Gregorio Martín Gutiérrez (ed.), Cineastas frente al espejo. Madrid: T\&B Editores, pp. 13-33.

Logie, Ilse (2015). «Más allá del "paradigma de la memoria”. La autoficción en la reciente producción posdictatorial argentina. El caso de 76 (Félix Bruzzone)», Pasavento. Revista de estudios hispánicos. III (1), pp. 75-89. Disponible en $<$ http://www.pasavento.com/ pdf/05_06_logie.pdf> [última visita: 10.11.2015].

Meizoz, Jerôme (2007). Postures littéraires. Mises en scène modernes de l'auteur. Ginebra: Slatkine.

Ouellette-Michalska, Madeleine (2007). Autofiction et dévoilement de soi. Montréal: ZYZ.

Pérez Bowie, José Antonio (2013). «La presentificación de la instancia narradora en el relato cinematográfico», en Marta Álvarez (ed.), Imágenes conscientes. AutoRepresentacioneS \# 2. Binges: Orbis Tertius, pp. 47-71.

Pozuelo Yvancos, José María (2010). Figuraciones del yo en la narrativa. Javier Marías y E. Vila-Matas. Valladolid: Cátedra Miguel Delibes.

Premat, Julio (2009). Héroes sin atributos. Figuras de autor en la literatura argentina. Buenos Aires: Fondo de Cultura Económica.

Prieto, Julio (2017). «Figuras digitales. Autoficción y prácticas fronterizas en la blogosfera», en Ana Casas (ed.), El autor a escena. Intermedialidad y autoficción. Madrid-Frankfurt: Iberoamericana-Vervuert, pp. 103-132.

Quílez Esteve, Laia (2008). «Sutiles pretéritos. (Post)memoria(s) y (auto)biografía(s) en el cine documental contemporáneo», en Gregorio Martín Gutiérrez (ed.), Cineastas frente al espejo. Madrid: T\&B Editores, pp. 83-99.

Quílez Esteve, Laia (2009). «Cuando el documentalista se ríe de sí mismo. La estética del fracaso y el documental performativo en Avi Mograbu, Ross McElwee y Alan Berliner», en Elena Oroz y Gonzalo de Pedro Amatria (eds.), La risa oblicua. Tangentes, paralelismos e intersecciones entre documental y humor. Madrid: Ayuntamiento de Madrid, pp. 117-133.

Richard, Annie (2013). L'autofiction et les femmes: un chemin vers l'altruisme? París: L'Harmattan.

Robin, Régine (1997). Le Golem de l'écriture. De l'autofiction au cybersoi. Montréal: XYZ.

Sagaseta, Julia E. (2006). «La vida sube a escena. Sobre formas biográficas y teatro», Telón de fondo. Revista de teoria y crítica teatral. 3, pp. 1-13. Disponible en $<\mathrm{http}: / / \mathrm{www}$. telondefondo.org> [última visita: 17.01.2015].

Schmitt, Arnaud (2007). «La perspective de l'autonarration», Poétique. Revue de théorie et d'analyss littéraires. 149, pp. 15-29. https://doi.org/10.3917/poeti.149.0015 
Schmitt, Arnaud (2010). Je réel / Je fictif, Au-delà d'une confusion postmoderne. Toulouse: Presses universitaires du Mirail.

Schmitt, Arnaud (2011). «Making the Case for Self-Narration against Autofiction», a/b: Auto/ Biography Studies. 25.2, pp. 122-137. https://doi.org/10.1353/abs.2010.0012

Schmitt, Arnaud (2014). «La autoficción y la poética cognitiva», en Ana Casas (ed.), El yo fabulado. Nuevas aproximaciones críticas a la autoficción. Madrid/Frankfurt: Iberoamericana/Vervuert, pp. 46-64.

Souquet, Lionel (2014). «Una autoficción 'espectacular’: Pedro Lemebel y Fernando Vallejo», en Ana Casas (ed.), El yo fabulado. Nuevas aproximaciones críticas a la autoficción. Madrid-Frankfurt: Iberoamericana-Vervuert, pp. 247-267.

Toro, Vera (2010). «La auto(r)ficción en el drama», en Vera Toro, Sabine Schlickers y Ana Luengo (eds.), La obsesión del yo. La auto(r)ficción en la literatura española y latinoamericana. Madrid-Frankfurt: Iberoamericana-Vervuert, pp. 229-250.

Tossi, Mauricio (2015). «Docudrama y autoficción en el teatro argentino de la posdictadura», Pasavento. Revista de estudios hispánicos. III (1), pp. 91-108. Disponible en $<$ http://www.pasavento.com/pdf/05_07_tossi.pdf> [última visita: 10.11.2015].

Tossi, Mauricio (2017). «Condiciones estético-políticas de la autoficción teatral», en Ana Casas (ed.), El autor a escena. Intermedialidad y autoficción. Madrid-Frankfurt: Iberoamericana-Vervuert, pp. 59-80.

Trastoy, Beatriz (2002). Teatro autobiográfico. Los unipersonales de los 80 y 90 en la escena argentina. Buenos Aires: Nueva Generación.

Trastoy, Beatriz (2006). «La escritura autobiográfica en el escenario y en la pantalla: una cuestión de estilos (Acerca de Notas de tango de Rafael Filippelli)», Telón de fondo. Revista de teoría y crítica teatral. 4, pp. 1-14. Disponible en $<$ http://www.telondefondo. org > [última visita: 17.01.2015].

Vásquez Rodríguez, Gilberto D. (2014). «Condición de verdad y ficción. Las literaturas del recuerdo y autoficción», en Ana Casas (ed.), El yo fabulado. Nuevas aproximaciones críticas a la autoficción. Madrid-Frankfurt: Iberoamericana-Vervuert, pp. 80-105.

Fecha de recepción: 8 de febrero de 2016 .

Fecha de aceptación: 19 de julio de 2016. 